116 Original Investigation / Özgün Araştırma

\title{
Economic Losses During an Outbreak of Simulium(Wilhelmia) Species (Diptera: Simuliidae) in the Cappadocia Region of Turkey
}

\author{
Türkiye`de Kapadokya Bölgesinde Simulium (Wilhelmia) Türlerinin (Diptera: Simuliidae) \\ İstilasında Oluşan Ekonomik Kayıplar
}

\author{
Savaş Sarı̈̈zkan', Abdullah Inci², Alparslan Yıldırım², Önder Düzlü², Elmer W. Gray³, Peter H. Adler \\ 'Department of Animal Health Economy, Erciyes University Faculty of Veterinary Science, Kayseri, Turkey \\ ${ }^{2}$ Department of Parasitology, Erciyes University, Faculty of Veterinary Medicine, Kayseri,Turkey \\ ${ }^{3}$ Department of Entomology, University of Georgia, Georgia, USA \\ ${ }^{4}$ Department of Forest and Environmental Sciences, Clemson University, School of Agricultural, Clemson, USA
}

\section{ABSTRACT}

Objective: The aim of this study was to calculate the economic losses during an outbreak of Simulium (Wilhelmia) spp. in the Cappadocia Region of Turkey.

Methods: The economic costs associated with a 2006-2007 outbreak of Simulium (Wilhelmia) spp. in the Cappadocia region of Turkey were calculated by summing losses to the livestock (dairy) industry and tourism (hotels), plus ongoing control expenditures.

Results: More than 2.000 .000 domestic and foreign tourists, 60.000 animals, and the local population were disturbed by the flies. Tourism was the most affected sector from the Simulium outbreak.

Conclusion: The calculated cost of the outbreak according to 2013 prices was 10.626 .966 TL (US\$5.45 million).

(Turkiye Parazitol Derg 2014; 38: 116-9)

Key Words: Bacillus thuringiensis subsp. israelensis, black flies, Cappadocia, economic impact, livestock

Received: 18.11 .2013

Accepted: 09.12.2013

\section{ÖZET}

Amaç: Bu çalışmanın amacı, Kapadokya Bölgesinde Simulium (Wilhelmia) türlerinin istalası nedeniyle oluşan ekonomik kayıpların hesaplanmasıdır.

Yöntemler: Simulium (Wilhelmia) türlerinin istilası nedeniyle 2006-2007 yıllarında oluşan ekonomik kayıplar, hayvancılık (süt sığırcılığı), turizm (oteller) ve kontrol harcamalarının toplanmasıyla hesaplanmıştır.

Bulgular: Toplamda, 2.000.000'dan fazla yerli ve yabancı turist ile bölgedeki nüfusun yanında 60.000 civarında hayvan sinekler tarafından rahatsız edilmiştir. Simulium istalasından en fazla turizm sektörü etkilenmiştir.

Sonuç: Sinek istilasının maliyeti, 2013 yılı cari fiyatlarıyla 10.626.966 TL (US\$ 5.45 million) olarak hesaplanmıştır. (Turkiye Parazitol Derg 2014; 38: 116-9)

Anahtar Sözcükler: Bacillus thuringiensis subsp. israelensis, kara sinek, Kapadokya, ekonomik etki, hayvancılık Geliş Tarihi: 18.11.2013

Kabul Tarihi: 09.12.2013

The Abstract of this study was presented at the "1.Vectors and Vector Bone Diseases Symposium", held on 9-10 September 2012, Avanos, Turkey

*Bu çalışmanın özeti "1. Ulusal Vektörler ve Vektörlerle Bulaşan Hastalıklar Sempozyumu"nda sözlü bildiri olarak sunulmuştur. Address for Correspondence / Yazışma Adresi: Dr. Savaş Sarı̈̈zkan, Department of Animal Health Economy, Erciyes University Faculty of Veterinary Science, Kayseri, Turkey. Phone: +90 3522076666 E-mail: ssariozkan@erciyes.edu.tr DOI:10.5152/tpd.2014.3446

(C) Copyright 2014 Turkish Society for Parasitology - Available online at www.tparazitolderg.org

@Telif hakkı 2014 Türkiye Parazitoloji Derneği - Makale metnine www.tparazitolderg.org web sayfasından ulaşılabilir. 


\section{INTRODUCTION}

Turkey's Cappadocia region lies in Eastern Anatolia (Asia Minor) and consists of a plateau more than $1000 \mathrm{~m}$ in altitude, pierced by volcanic peaks, including Erciyes Mountain (3916 m). The inland location and high altitude produce a continental climate with hot, dry summers and cold, snowy winters; rainfall is sparse, and the region is largely semi-arid (1). The principal river of the Cappadocia region is the 1150-km-long Kızılırmak River, which originates in Eastern Anatolia and eventually empties into the Black Sea.

Unique geological, historical, and cultural features make the Cappadocia region a popular tourist destination. However, construction of the hydroelectric Yamula Dam in Kayseri, completed in 2005, was followed by a severe outbreak of black flies along the Kızılırmak River below the dam (2). Affected locations included Yemliha (the nearest location to Yamula Dam) in Kayseri Province and the important tourist districts of Avanos, Gülşehir, and Ürgüp in Nevşehir Province. Local citizens first reported a black fly problem in 2005, which reached an intolerable level in 2006. Workers were unable to enter the vineyards, orchards, fields, and pastures; hotels suffered vacancies; livestock were distracted by attacks; and tourists often were unable to breathe or function comfortably with swarms of flies about them (2). Farmers resorted to classic methods of control, such as wearing head nets and producing smoke by burning dung (2). Management using Bacillus thuringiensis subsp. israelensis (Bti)based larvicides was initiated in August 2007.

Black flies are important pests throughout the world (3), but quantitative data on their economic effects are scarce. Calculated losses typically involve black fly attacks on livestock, especially in Canada and the USA (4). Costs to commercial sectors, such as the car wash, paper, and tourist industries, and to local economies have been reported less frequently (4). For instance, Gray et al. (5) reported economic losses for the state of South Carolina, USA, by black flies on a single golf course. Our objective is to present the economic losses to livestock production and tourism, plus control expenditures, associated with a 20062007 outbreak of black flies in the Cappadocia region of Turkey.

\section{METHODS}

Larvae and pupae were collected from the Kizilirmak River throughout each year from 2006-2012, and adults were collected from swarms around people in the summer of the outbreak. Immatures were identified morphologically and chromosomally, whereas adults were identified morphologically $(6,7)$. Voucher specimens were deposited in the Clemson University Arthropod Collection.

The cost of the outbreak was calculated by combining losses to livestock farmers and hotel operators, plus expenses incurred by the local and central governments for ongoing suppression. Losses to the livestock industry, especially for dairy cows, were based on official data of the Turkish Statistical Institute (8) and personal communication with local milk producers. The cost of the infestation to the dairy industry was estimated by comparing the average milk production by animals before the outbreak (2004-4005), during the outbreak (2006-2007), and after the outbreak (2008-2009), when suppression activities were in place. Losses to hotels, in terms of cancellations and reduced stays, were obtained from surveys of the operators of nine hotels. Costs incurred by the central and local governments included those associated with identifying the pest problem, developing and staffing a suppression program, and purchasing the larvicide necessary for implementing the program. Losses were calculated according to 2013 prices and converted to US\$ (1 TL = US\$ 0.51).

\section{RESULTS}

Identification of samples of larvae and pupae revealed that the simuliid fauna in the Kizilirmak River consisted almost exclusively (>99\%) of two species in the subgenus Wilhelmia, with roughly $90 \%$ being S. lineatum (Meigen) and the remainder S. balcanicum (Enderlein). Samples of adult females consisted entirely of S. lineatum/balcanicum. These two species are morphologically inseparable as adults (7); hence, their relative contributions to the pest problem are not known.

Annual livestock production in the Cappadocia region has been increasing, but official data (8) and milk producers indicated production losses on dairy farms (decreased milk production per cow). By using these data, we estimated that infestation caused 775.892 TL (US\$ 651.749) in losses for dairy production (Table 1).

As a result of the wide range of people affected by the outbreak in the Cappadocia region, a black fly suppression program using Bti-based larvicides was initiated in August 2007 (2). The local government provided a total of $246.291 \mathrm{TL}$, or $14 \%$ of the total suppression program, including an initial amount for preliminary investigation of management possibilities in 2006. The Turkish central government began supporting the program in 2007 and provided 1.504.783 TL (US\$ 771.683) for suppression efforts through 2012. The total cost of black fly suppression to the local and central governments was 1.751.074 TL (US\$ 897.986; Table 2).

The cumulative cost of the outbreak to the Turkish economy as a result of negative impacts on dairy production (775.892 TL; 7.3\%) and tourism (8.100.000 TL; 76.2\%), plus suppression expenses (1.751.074; 16.5\%), was 10.626.966 TL (US\$ 5.45 million).

\section{DISCUSSION}

Productivity losses for beef cattle and fattening lambs were not detected, possibly because the production system involves

Table 1. Milk production in dairy cattle before, during, and after a Simulium outbreak in the Cappadocia Region of Turkey (8).

\begin{tabular}{|c|c|c|c|}
\hline & $\begin{array}{l}\text { Before } \\
\text { outbreak }\end{array}$ & $\begin{array}{l}\text { During } \\
\text { outbreak }\end{array}$ & $\begin{array}{c}\text { After } \\
\text { outbreak }\end{array}$ \\
\hline Year & (2004-2005) & (2006-2007) & (2008-2009) \\
\hline Productivity (mean) & 2778 It/cow & $2780 \mathrm{lt} / \mathrm{cow}$ & $2913 \mathrm{lt} / \mathrm{cow}$ \\
\hline Interpolation & \multicolumn{3}{|c|}{$(2778+2913) / 2=2845 \mathrm{It} / \mathrm{cow}$} \\
\hline Difference (Loss) & \multicolumn{3}{|c|}{$2845-2780=65$ liters/cow } \\
\hline $\begin{array}{l}\text { Number of dairy } \\
\text { cows }\end{array}$ & \multicolumn{3}{|c|}{14.921 head } \\
\hline Total Losses & \multicolumn{3}{|c|}{$\begin{array}{c}14.921 \text { cows } \times 65 \text { liters } \times 0.8 \mathrm{TL} / / \mathrm{t} \\
=775.892 \mathrm{TL}\end{array}$} \\
\hline
\end{tabular}


Table 2. Control expenses by the central and local governments for suppression of black flies (12)

\begin{tabular}{|l|c|c|c|}
\hline Year & $\begin{array}{c}\text { Central } \\
\text { Government }\end{array}$ & $\begin{array}{c}\text { Local } \\
\text { Government }\end{array}$ & Total \\
\hline 2006 & - & 46.166 & 46.166 \\
\hline 2007 & 374.562 & 12.325 & 386.887 \\
\hline 2008 & 328.125 & 33.034 & 361.159 \\
\hline 2009 & 447.090 & 22.188 & 469.278 \\
\hline 2010 & 117.808 & 63.524 & 181.332 \\
\hline 2011 & 128.448 & 64.404 & 192.852 \\
\hline 2012 & 108.750 & 4.650 & 113.400 \\
\hline Total & & & $1.751 .074 \mathrm{TL}$ \\
\hline
\end{tabular}

closed barns and a shortened fattening period. Black flies typically do not enter buildings for blood meals (3). Levels of simuliid-borne leucocytozoon disease among turkeys in South Carolina, USA, for example, were reduced when the birds were moved to indoor facilities (4).

The Cappadocia region supports a robust tourism industry of approximately 2 million domestic and foreign tourists per year (9), which has increased annually since 2004. However, the black flies caused significant problems at hotels in the affected area, particularly at three of the largest hotels (Avrasya, Mustafa, and Yiltok Hotels), which maintain training complexes for football (USA soccer). The black flies caused teams to cancel their 15-day training visits. Hotel operators reported 6000 cancellations during the outbreak. The total loss associated with 6000 cancellations over 15 days at the all-inclusive, average daily accommodation price of $90 \mathrm{TL} /$ person, totaling 8.100.000 TL. During the black fly seasons of the 1970s, tourism declined by $85 \%$ in a town in New Hampshire, USA, resulting in an annual loss of $\$ 244.800$ (10), while a suppression program in a town in New York's Adirondack Mountains boosted tourism by $\$ 367.500$ per year (11).

\section{CONCLUSION}

This study represents the first time the cost of a simuliid outbreak was estimated using with livestock production losses, control expenses and tourism figures (12). We did not calculate costs to agriculture that resulted from failures to harvest at the proper time, the associated losses in product value, or additional labor and time losses, nor did we evaluate potential losses to tourism associated with negative publicity, reduced employment in the industry, or the intangible reduction in quality of life to the residents. Our calculated costs associated with the Simulium outbreak, therefore, are highly conservative.

Ethics Committee Approval: Ethics committee approval was not received due to the retrospective nature of this study.

Peer-review: Externally peer-reviewed.

Author Contributions: Concept - S.S., A.I.; Design - S.S., A.I.; Supervision - E.W.G., P.H.A.; Materials - S.S., A.I.; Data Collection and/or Processing - S.S., A.Y., Ö.D.; Analysis and/or Interpretation
- S.S., A.Y., Ö.D.; Literature Review - S.S., E.W.G., P.H.A.; Writing - S.S., E.W.G., P.H.A.; Critical Review - S.S., A.Y., A.I.

Acknowledgements: This study was a product of a research project supported by The Scientific and Technological Research Council of Turkey (TUBITAK, Project no: 1110426). The authors also would like to thank to Dr. Hieko Kotter and Dr. Robert Fusco from Valent BioSciences, Dr. Abdullah Yilmaz, Veterinarian Hakan Yesiloz and Ahmet Demircioglu for their contribution to characterize the river and provided initial guidance for the Bti applications.

Conflict of Interest: No conflict of interest was declared by the authors.

Financial Disclosure: The authors declared that this study has received no financial support.

Etik Komite Onayı: Çalışmamızın retrospektif tasarımından dolayı etik komite onayı alınmamıştır.

\section{Hakem değerlendirmesi: Dış bağımsız.}

Yazar Katkıları: Fikir - S.S., A.I.; Tasarım - S.S., A.I.; Denetleme E.W.G., P.H.A.; Malzemeler - S.S., A.I.; Veri toplanması ve/veya işlemesi - S.S., A.Y., Ö.D.; Analiz ve/veya yorum - S.S., E.W.G., P.H.A.; Literatür taraması - S.S., E.W.G., P.H.A.; Yazıyı yazan - S.S., E.W.G., P.H.A.; Eleştirel İnceleme - S.S., A.Y., A.I.

Teşekkür: Bu çalışma Türkiye Bilimsel ve Teknolojik Araştırma Kurumunca desteklenen bir araştırma projesinin ürünüdür (TÜBITAK, Proje no: 1110426). Yazarlar ayrıca Dr. Hieko Kotter ve Valent BioScience'dan Dr. Robert Fusco'ya, Dr. Abdullah Yılmaz'a, Veteriner hekim Hakan Yeşilöz'e ve Ahmet Demircioglu'na nehirleri karakterize etmede ve BTI uygulamalarına rehberlik etmede gösterdikleri katkılarından dolayı teşekkür eder.

Çıkar Çatışması: Yazarlar çıkar çatışması bildirmemişlerdir.

Finansal Destek: Yazarlar bu çalışma için finansal destek almadıklarını beyan etmişlerdir.

\section{REFERENCES}

1. Van Dam R. Kingdom of Snow: Roman Rule and Greek Culture in Cappadocia. Philadelphia: University of Pennsylvania Press; 2002.

2. Yılmaz A, İnci A, Tunçbilek AS, Yeşilöz $H$, Koçak Ö, Şirin Ü, İça A, Yıldırım A, Demircioğlu A, Düzlü Ö. Orta Kızılırmak havzasında karasinek (Simulium (Wilhelmia) lineatum) (Diptera: Simuliidae) istilası. Erciyes Üniv Vet Fak Derg 2007; 4: 91-5.

3. Adler PH, McCreadie JW. Black flies (Simuliidae). In: Mullen GR, Durden LA, eds. Medical and Veterinary Entomology. San Diego, CA: Elsevier. 2009. p. 189-206.

4. Adler PH, Currie DC, Wood DM. The Black Flies (Simuliidae) of North America. Ithaca, NY: Cornell University Press; 2004.

5. Gray EW, Adler PH, Noblet R. Economic impact of black flies (Diptera: Simuliidae) in South Carolina and development of a localized suppression program. J Am Mosq Control Assoc 1996; 12 676-8.

6. Weber EA, Grunewald J. Cytotaxonomic differentiation of Wilhelmia equina (Linné, 1747) and Wilhelmia lineata (Meigen, 1804) (Diptera: Simuliidae). Genome 1989; 32: 589-95. [CrossRef]

7. Crosskey RW and Zwick H. New faunal records, with taxonomic annotations, for the blackflies of Turkey (Diptera, Simuliidae). Aquatic Insects 2007; 29: 21-48. [CrossRef] 
8. TUiK. 2012. Türkiye İstatistik Enstitüsü. Hayvanclık İstatistikleri. http://tuikapp.tuik.gov.tr/hayvancilikapp/hayvancilik.zul (Accessed 01 September 2012).

9. Anonymous. 2012a. Nevşehir il Kültür ve Turizm Müdürlüğu. Available from: http://www.nevsehirkulturturizm.gov.tr/ana-sayfa/ 1-39401/20121001.html
10. Martin JW. The black flies (Diptera: Simuliidae) in Waterville Valley, New Hampshire. MSc, University of New Hampshire, Durham, NH. 49 pp. 1981.

11. Elliott L. Biting back. Adirondack Life 1983; 14: 37-40.

12. Anonymous. 2012b. T.C Nevşehir il Özel Idaresi. Available from: http://www.nevsehirozelidare.gov.tr/ 